\title{
Remarks on the Question of the So-Called Monastic Schools of Architecture
}

\author{
Ernő Marosi \\ Institute of Art History, Research Centre for the Humanities, ELKH, 1453 Budapest, P.O.B. 33, \\ Hungary; Marosi.Erno@abtk.hu
}

Received 25 May 2020 | Accepted 02 October 2020 | Published online 30 April 2021

\begin{abstract}
The hypothetical interpretation of the beginnings of monastic architecture in Hungary in the eleventh century as corresponding to the Italian origin of the clergy cannot be proved, and the beginning of the dominating role of a three-apsidal, axially organized basilica in Hungary cannot be traced earlier than the last quarter of the eleventh century.

The dominance of the type, which has been considered in Hungarian art history since the nineteenth century as a "national" building type, can be dated as of the last quarter of the eleventh century. It is not only the problem of monastic architecture, because the same typology-in other dimensionsis also characteristic of other church buildings-cathedrals and provostry churches.

However, it is apparent that both in the case of monasteries and in other genres of church buildings, the Hungarian solutions are minimal and less complicated. There is an important written source concerning the value of the patronage of church buildings. The so called Estimationes communes iuxta consuetudinem regni (i.e. common estimations) go back to Romanesque times and they were still accepted in 1516 by the printed edition of Decretum tripartitum by István Werbőczy. The classification of ecclesiastic property was governed by two criteria: the value of the building and the possession of the right of sepulture.
\end{abstract}

The architectural heritage of the Cistercians appears as a rather uniform stylistic phenomenon. This uniformity was interpreted in the art historical literature as a contribution by the order supposedly having an own building organization. But the hypothesis that the workers, the conversi of the order were among the other craftsmen and builders of churches and monasteries of the order has been revealed as a legendary interpretation of art history.

The most active period of the Hungarian Cistercians began with the privileges given by King Béla III to the Order and with the foundation of three abbeys in the 1180s. The very rational and well-organized building activity of the Cistercians and also the effective control coming from the top of their centralized organization has been presumably considered as unusual by contemporary observers.

To prevent the excessive influence of secular people and to improve the education of the monks, the centralized organization was proposed for the Benedictines too. This reform was initiated by popes of the time about 1200, Innocent III and also Honorius III. It seems that the necessary reform 
as well as the solution of the problems by adopting the experience of the Cistercians influenced the spread of the regular monastery building under the evident intention of imitation. Quadratic interior courts framed by open galleries and surrounded by the most important common rooms, including the chapterhouse and refectory of the monastery, appear evidently from about 1220 in Hungarian Benedictine architecture.

The Praemonstratensians, a reform order, was a nearly contemporary parallel to the Cistercians. In the twelfth century and also at the beginning of the thirteenth they were in fact in a straight contact with the Cistercians, who exercised a kind of control over the order, whose rules were not derived from the Benedictine rules but were based on the rules of St Augustine. Mainly the centralized organization of the order could correspond to the Cistercian model. The main difference between these reform orders concerned their patronage. While the Cistercians in Hungary were mostly under royal patronage (mainly after the visit of a delegation of Cîteaux to the Court of Béla III in 1183), the Praemonstensian constructions were mainly foundations by private patrons.

It seems that contrary to partly surviving hypotheses and forgeries in old art historical literature, no royal court and also no monastic order was practically involved in architecture or building praxis, including schools of architecture. Their relationship was different, corresponding to their liturgy and to the representation of their self-image.

Keywords: monastic orders, Benedictines, monastic reform, centralized orders, Cistercians, Praemonstratensians, choir structure, right of sepulture, cloisters with regular shape

The art and architecture of the Middle Ages were discovered in the eighteenth and the early nineteenth century as corresponding to regional, local and at last, national characteristics. The romantic observer conceived of the warm and emotional culture of medieval art as opposed to the universal regularity of classical art. Later in the nineteenth century the concept of nationally colored various decadences of Antiquity gave way to the universal historical epoch of the Romanesque, the dominating universal phenomenon being reunited with Christianity and its institutions. Mainly monasticism was identified by art history as such a connecting link. The theory of Viollet-le-Duc can also be mentioned, according to which two basic types of mentality dominated medieval art: the earlier esprit monastique as the foundation of the Romanesque style, replaced on the climax of urban development by esprit laïque of the towns. In the course of history, not only individual monastic institutions, but also diverse alliances of monasteries united by different reforms of monasticism played an important role. Monastic reforms produced different organizations, liturgical customs and regulations of the everyday life, as well as chains of associated monasteries, such as the members of the congregation around Cluny or Hirsau in South Germany and also the Scottish congregation in Germany, among others. ${ }^{1}$

1 Some selected works from the immense literature: Evans, Romanesque Architecture; Conant, Cluny; Mettler, "Die zweite Kirche [1909/1910]"; Mettler, "Die zweite Kirche [1910/1911]"; 
Today, speaking about medieval architecture in Hungary we mean architecture determined by the above-mentioned factors of monastic life. Unlike in Western and Southern Europe, Hungary as well as its East European neighbors did not have a long past of the Christian Church around the year 1000, as they had just converted to Christianity. The beginning of the Hungarian Romanesque architecture can be considered as an exemplary case. ${ }^{2}$ According to the tradition, the first Romanesque in Hungary reflects the Italian and monastic origin of the Church. The monks of the first Benedictine monastery of Pannonhalma, founded by duke Géza before or in 996 the latest and consecrated in 1002 under King Stephen, came from Italy, and the connection was also expressed by the relationship between the Hungarian monastery and its supposed model, the church of SS. Alessio e Bonifacio on the Aventine Hill in Rome. ${ }^{3}$ The church of Pannonhalma monastery, a product of three medieval construction periods is a rather modest building measured to bigger and more complicated contemporary buildings such as the nearly parallel built Burgundian St Benigne in Dijon belonging to the immediate circle of Cluny, or the eleventh-century church of Abbot Desiderius in Monte Cassino, head of the Benedictine order. Apart from their basilical structure with a nave and two aisles and a crypt, there is no similarity between the Hungarian and the Roman churches. Even the wide apse of SS. Alessio and Bonifacio is missing in Pannonhalma and up to the transformation in the early nineteenth century the entrance to the Hungarian church was not directed axially. A western apse above a crypt was built in Pannonhalma, which was first discovered on a measured drawing of the eighteenth century and then also by excavation. So, the fact that the Pannonhalma church belonged to the church buildings of Ottonian Germany shaped with double apsides could be proved. Even in the third building of the early thirteenth century the western choir above the crypt was rebuilt and only went into oblivion in the nineteenth century. ${ }^{4}$

It is thus unsubstantiated to trace the beginnings of monastic architecture in Hungary in the eleventh century to the Italian origin of the clergy, and also the dominant role of a three-apsidal, axially organized basilica in Hungary can only be

Hoffmann, Hirsau; Schürenberg, "Mittelalterlicher Kirchenbau," 23.

2 Cp. Marosi, "Bencés építészet," 131-42.

3 Levárdy, "Pannonhalma építéstörténete. I.," 27-43; Levárdy, "Pannonhalma építéstörténete. II.,” 101-29. here: 101, 103. f.; Levárdy, “Pannonhalma építéstörténete. III.,” 220-31; cp. Gerevich, Magyarország románkori emlékei; Dercsényi, "A honfoglalás," 20. f.. For the hypothesis of a Benedictine style, see: Ipolyi, "Magyarország középkori emlékszerủ építészete," 37. ff.

4 Tóth, "A művészet Szent István korában," Fig. 117 and 8.; Concerning the building type, see note 47. and also note 45.; The results of the archaeological investigation: László, "Régészeti adatok," 143-69; about the hypothesis of a Western transept see Takács, "Pannonhalma újjáépítése," 176-84 and Fig. 16. 
supposed as of the last quarter of the eleventh century. Surprisingly enough, instead of uniformity, a relatively rich variation can be observed. Pannonhalma had no entrance on the west facade similarly to e.g. the Salian Hersfeld or the reform building of SS Peter and Paul in Hirsau, but it is also possible that this western apse was bound to a transept more romano, as in St Michael's in Hildesheim. Apparently, crypts had an important role in the early monastic architecture in Hungary. If Pannonhalma had two crypts from the start, one of them could be the place of the cult of relics and the other, on the east end served perhaps another liturgy. Under the elevated choir of the monastery church of Feldebrö dedicated to the Holy Cross, there was a fully developed architectural system of the crypts with a western wall with windows giving insight into it as in a Roman confessio arrangement and it was also enlarged by an adjoining tomb chamber. ${ }^{5}$ It is interesting that this western liturgical system was sometimes combined with a central shape of the Byzantine type, like the Szekszárd monastery church dedicated to Our Saviour and built earlier as the funerary church of King Béla I. ${ }^{6}$ It seems likely that the rich variations of the monasteries were connected to the phenomenon of the Eigenkirche, target of vehement struggles between Papacy and Empire in the first Investiture controversy. The monastery of King Andrew I in Tihany, ${ }^{7}$ a relatively well-dated building of the 1060s with an axial shape and a still extant three-aisled crypt, seems to be rather characterized by western orientation, while the monastery of Palatine Otto in Zselicszentjakab ${ }^{8}$ is more like a Byzantine building. The type of the three-apsidal basilica without a transept even appeared in monasteries where kings and high nobility were buried from the late eleventh century. Whether they had or had not a crypt ${ }^{9}$ was perhaps decided by the fact that at the Council of Guastalla the ambassadors of King Coloman declared in 1106 the renunciation of the right to investiture and other ecclesiastical privileges. Thus, the beginning of the dominance of the type identified in Hungarian art history as a "national" building type since the nineteenth century is to be dated to the time beginning with the last quarter of the eleventh century. The spread of this types was attributed to the Benedictine order and later not only the transmission of

5 As a modern history of Benedictine Romanesque architecture in Hungary is lacking, we cite the short monographical articles of different authors (the major part of them by Imre Takács and Sándor Tóth) in the exhibition catalogue Takács, Paradisum as well as the critical catalogue of the monasterology of the Hungarian Benedictine communities by Hervay, "A bencések és apátságaik," 476-547; Feldebrő: Hervay, "A bencések és apátságaik," 541.

6 Tóth, "Szekszárd," 339-41; Hervay, "A bencések és apátságaik," 541.

7 Tóth, “Tihany,” 335-38; Hervay, "A bencések és apátságaik," 513-14.

8 Tóth, “Zselicszentjakab,” 341-46; Hervay, “A bencések és apátságaik,” 527-28.

9 Somogyvár: Papp and Koppány, "Somogyvár," 350-53; Hervay, "A bencések és apátságaik," 509-11; Hronský Beňadik (Garamszentbenedek): Hervay, “A bencések és apátságaik,” 490-92; Rakovac (Dombó): Tóth, “Dombó,” 359-67; Hervay, “A bencések és apátságaik," 487. 
the building types but also the execution of the buildings was thought to have been the work of monastic workshops.

This is not only the problem of monastic architecture, because the same typology - in other dimensions - is also characteristic of other church buildings: cathedrals and provostry churches. In 1956 Dezső Dercsényi illustrated his text about the importance of the three-aisled basilica without a transept and with a double towered western part with plans drawn on the same scale. ${ }^{10}$ Modern synthetic studies could only be illustrated by drawings on an approximate scale. I can show a collection of the Romanesque building types in question published by my colleague Béla Zsolt Szakács nearly twenty years ago. ${ }^{11}$ As dimensions play an important role in this problem, I have to point out that my comparisons are not based on exact measurements, but only on approximate proportions.

However, it is apparently true of both monasteries and other genres of church buildings that the Hungarian solutions are minimal and less complicated. The donators seem to have looked for the cheapest possible solution in terms of both construction and the costs of the maintenance of these churches. The number of the inhabitants of the Hungarian monasteries was small; it was not higher than one or two dozen even in bigger royal monasteries such as Pannonhalma or Somogyvár, and there were only a few people in monasteries of the noble families. According to the calculations of the late Elemér Mályusz in his monography of the ecclesiastic society in Hungary, ${ }^{12}$ Pannonhalma could be inhabited by about forty persons in the thirteenth century, which number gradually sank to about ten at the end of the Middle Ages. Small monasteries housed originally four or five monks, and only one or two about 1500, which cannot be called "monastic life". In most of the cases it was impossible to pursue a real spiritual or scholarly life, maintain a scriptorium or a monastic school of higher importance from the foundation date on. It is not the same as in the big monasteries of Western Europe built for many hundreds of monks in several cases. It is characteristic enough that a lot of Hungarian monasteries devastated by the Mongols in 1241-1242 did not have economic power enough to restore their normal state and activity, and at the end of the Middle Ages, long before the Reformation, a number of monasteries of different orders were already in a state of total material and also moral desolation.

There is an important written source concerning the value of the patronage of church buildings. ${ }^{13}$ Contrary to the law based on the example of the holy kings, ${ }^{14}$

10 Dercsényi, “A pécsi műhely kora," 32 (Fig. 17); Dercsényi, “A román stílusú művészet fénykora," 93 (Fig. 66).

11 Szakács, “Állandó alaprajzok," 25-38.

12 Mályusz, Egyházi társadalom, 212-16.

13 Cp. Marosi, "Pfarrkirchen," 201-21.

14 The law is already cited in St Stephen's Legenda minor: percipiensque laboriosum fidelibus 
but following their activities as founders, ${ }^{15}$ the existence of such valuation expressed in different sums of money is in itself antithetical to the principle of refusing private property in the church as simony. ${ }^{16}$ Nevertheless, the late medieval legal practice shows the use of lists differentiating churches by their values in estate processes. The so-called Estimationes communes iuxta consuetudinem regni (i.e. common estimations) go back to Romanesque times and they were still accepted in 1516 by the printed edition of Decretum tripartitum by István Werbőczy. The classification of ecclesiastic property was based on two criteria: the value of the building and the possession of the right of sepulture. The most expensive category was that of a Monasterium sive Claustrum, sepulturam patronorum \& aliorum specialium Nobilium habens, estimated to hundred Marks of silver. If the possession of the rights of patronage was combined with the right of sepulture, the building might cost the double of a church without this right. Even the lowest category of wooden churches was worth five Marks with sepulture and only three Marks without it. Besides monasteries there was also a second category of churches under the patronage of noblemen, which had two (bell?) towers like monasteries (ecclesia cum duabus pinnaculis, ad modum Monasterii fundata. These towers could be ante et post vel in medio i.e. in front, behind or in the middle. The third category of patronage churches valued at twenty-five Marks of silver referred to buildings with a single belltower which did not belong to a monastery and were not built like a monastery.

The nobleman in possession of the right of patronage could be content with the right of sepulture for himself and for his family inside of the church and with a relatively monumental west facade with two towers. The remnants of the small monastery found in an archaeological campaign in Kána, close to Budapest, was a simple church like a parish church of a village but with a more complicated west part. ${ }^{17}$ As the influential French family of the thirteenth century, the Aynards came

esse, si illuc ab exterioribus locis ad missarum sollempnia confluerent, iussit, ut decem villarum populus ecclesiam edificaret, ad cuius diocesim pertineret, ne tedio affectus minus religionis sue officium curaret, Szentpétery, Scriptores, 396.

Cp. the text of the "Decretum S. Stephani" II, I. De regali dote ad ecclesiam. Decem ville ecclesiam edificent, quam duobus mansis totidemque mancipiis dotent, equo et iumento, sex bubus et duabus vaccis, XXX minutis bestiis. Vestimenta vero et coopertoria rex provideat, presbiterum et libros episcopi, Závodszky, A Szent István, 153.

15 Mályusz, Egyházi társadalom, 15-18.

16 Fügedi, "Sepelierunt corpus," 50, with data of 5 lists from the fifteenth century: 59. f.; Earlier: Bónis, "A somogyvári formuláskönyv," 127; Cp. Mezey, "Autour de la terminologie ecclésiastique," 381. Based on these publications, we have already considered the rights of patronage as elements of the wealth of a nobleman in: Marosi, Magyarországi müvészet, 115.

17 Hollné Gyürky, A Buda; Györffy, Az Árpád-kori Magyarország, vol. 4, 571; Hervay, "A bencések és apátságaik," 532. 
to Zsámbék, they found on the site a little rural church, which they used for the burial of a woman, mother of the most active family members. A small west part was also added to the first church, and the great church with a complicated west part containing a gallery and two side rooms (chapels?) was built over the aisles. A remarkable monastery church emerged, the estimated value of which corresponded to the category of hundred Marks of silver. ${ }^{18}$

On the other side, the provostry church in Felsöörs was perhaps a good example of the twenty-five-Mark category. Its single tower with the altar upstairs, dedicated to Saint Michael in the 1230s by the Bishop of Veszprém, was probably preceded by the nave. In the vaulted entrance hall, under the staircase leading to the altar upstairs, there is an arcosolium-grave, that is, a monumental burial site of one of the patrons. ${ }^{19}$ It seems that the western parts under the patronage of secular persons were often dedicated to the representation of the founders. ${ }^{20}$ We can also suppose the existence of other towers near the sanctuary, in the oriental part of the nave in several cases. The abbey church of Acâș (Ákos) seems to have had even two pairs of towers, twomaybe unfinished-towers on the east and a monumental pair on the west. ${ }^{21}$ This arrangement has parallels among the Romanesque cathedrals of the country, in Eger or even in Esztergom, where the east towers were still depicted as late as in 1730 . The common forms between monastic buildings, secular provostries and cathedrals were not limited on a few traits: there was no Benedictine school, but different centers contributed to a varied Romanesque architecture, which was specified by regional and chronologically determined phenomena, rather than by consuetudines of the monastic orders. Besides, the liturgical ordo did not show any specific features as the order's peculiarities, which is to be ascribed to the fact that except Pannonhalma and the royal monasteries, which had the privilege of exemption from the diocesan bishops, all Benedictine monasteries were subordinated to episcopal legislation. They were more bound by the culture and tradition of the regions, than by the country. In that age, patriotism was meant participation in the community of a region or diocese.

Acâș monastery belongs to the few church buildings that are characterized by the tradition of twelfth-century architecture. The pure geometric forms, prismatic pillars and very strict geometric construction, the avoidance of richer

18 About the stylistic situation of the great monastery church, see: Marosi, Die Anfänge der Gotik, 124, 155-58. The unearthing of the earlier church: Valter, "Újabb régészeti kutatások," 24-28.

19 Tóth, "Felsőörs," 26; Tóth, "A felsőörsi préposti templom," 53-76.

20 About types and functions of Western parts of church buildings, see: Entz, "Nyugati karzatok," 130. ff.; Reconsideration in a Central European framework: Tomaszewski, Romańskie kościóly; Cp. Entz, "Még egyszer a nyugati karzatokról," 133-41.

21 Ákosmonostora: Hervay, “A bencések és apátságaik," 538; Boldva: Hervay, “A bencések és apátságaik,” 540; Cp. Tóth, “A 11-12. századi,” 255-58; Szakács, “Ákos,” 86-91. 
ornamental and figural decoration all belong to a circle of influences coming from South Germany. The Scottish Benedictine church of St James in Regensburg can be cited for its style and its east towers, and also as a model for this architecture. The construction date of Acâș can only be based on stylistic observations. Another Benedictine church, the one in Boldva which was already restored in the early thirteenth century, can be dated with more probability to the twelfth. Here, too, the pure and ascetic prismatic forms represent South German monastic traditions. Despite multiple reconstructions, the relatively small church conserved very important traits of its liturgical arrangement. The east towers were opened with wide arcades onto the choir quadrant of the church. Access to the galleries was ensured by staircases in the thickness of the wall. The singers of the monastery had to start in the nave to ascend to the gallery, where they represented the angelic choir. ${ }^{22}$ These boys' choirs had an important role in dialogic chants on the feast of the Nativity and also during the Triduum before Easter. They represented the shepherds and the Wise Men of the Orient in the play entitled Tractus Stellae as well as sang the parts of the liturgy from the Adoration of the Cross through and the Holy Sepulchre to the Resurrection.

In the rigorous simplicity of the church buildings in the tradition of the German reform movements the ornamental and also figural decoration was concentrated on the sanctuary. Not only the Benedictines, but also their ecclesiastic contemporaries installed their choirs (chori majores) as places of the monastic community at mass but also for the chanting of the Psalms. The continuation of the liturgical choir, often closed westward by roodscreens separating the clerical community from the secular people, was named in more complex monasteries chorus minor or schola cantorum. Naturally, the use of boys' choirs in the liturgy depended on the existence of schools, which was rather exceptional among Hungarian monasteries. From the eleventh century on, when St Hadrian's in Zalavár, a foundation of St Stephen got its white marble choir furniture, remnants of very rich decoration on separating walls of the choirs witness the presence of the most important styles. The common use of these sculpted and also painted decorations show the same parallel evolution as other phenomena of architecture. About the end of the eleventh century, the Byzantine ornaments of the choirs gave way to early figural sculptures. The latter can mainly be found among the carved fragments of the iconostases of Rakovac (Dombó) monastery in today's Serbia. The rich sculptural arrangement of the royal provostry church of St Peter's in Obuda was the model for a similar choir furniture in the royal Abbey of Somogyvár about the mid-twelfth century, and a single ornamental sculpture confirms that the same masters were also active in Pannonhalma. ${ }^{23}$ At the height of Romanesque

22 Marosi, "Megjegyzések," 88-116, especially: 101-2; Marosi, “A Pray-kódex," 11-24. Cp. Karsai, "Középkori vízkereszti játékok," 73-112.

23 About choir balustrades and rood screens, see: [Zalavár] Mikó and Takács, Pannonia Regia, 
art two cathedrals, the one in Pécs from the late twelfth century and the early thirteenth-century church in the Transylvanian bishop's seat Alba Iulia (Gyulafehérvár) display the highest standards of figural elements originally belonging to choir ensembles. The type and form of the choir enclosure in Pécs is one of the most problematic questions. ${ }^{24}$ The subjects represented in the relief series only constitute a little part of a rich composition. The original choir in Alba Iulia was perhaps separated from the nave by a rood screen, which was decorated by relief tables secondarily used over the counterforts of the new choir of the cathedral after the mid-thirteenth century. ${ }^{25}$

The most striking feature of Romanesque architecture in Hungary concerned the scale of its dimensions - not only those of monastic architecture, but of the cathedrals too. Comparisons of ground-plans do not only indicate differences of dimensions, but also suggest a reduction to the minimum of the liturgical functions of the Hungarian private monasteries. One of the richest private monasteries, that of Ják appears small in comparison with both the already quoted Bavarian monastery of St James in Regensburg and its apparently immediate artistic model, the cathedral in Bamberg. A thirteenth-century series of late Romanesque structures with a tendency to receive early Gothic structural solutions are characterized by the use of octagonal piers in their nave. All churches concerned were probably built in the first three decades of the thirteenth century: the Praemonstratensian church of Ócsa and the Benedictine churches in Arača (Aracs) and Vértesszentkereszt. Ócsa, which was already mentioned in the so-called Ninive catalogue of Praemonstratensian communities in 1234, indicates that the framework for these buildings was not given by a monastic order, but by a common artistic relationship. The early Gothic character of these constructions with Gothic vaulting can be proved by still conserved or reconstructed sections of the naves. Among these monuments the Benedictine monastery church was the smallest. Digging for the twelfth-century roots of the common architectonic system of this series, we find Laon cathedral as the general model and its German reduction in St George's in Limburg an der Lahn as a link of transmission. The Limburg Cathedral can approximately correspond to the core building of Laon in its original form, but it is not more than about a third of its size. Arača was about half as long as Limburg and also its four-stories elevation was simplified. The comparison of the ground-plans may indicate the reduction in scale, while the interiors can show a more intricate relationship in the solutions of the vertical structures. ${ }^{26}$

Cat. No. I-23,24, 80-82; [Dombó] Stanojev, “A dombói,” 383-428; Tóth, Román kori köfaragványok, 11-38, 39-42; [Óbuda] Mikó and Takács, Pannonia Regia, Cat. No I. 56, 110-11, Tóth, Román kori kőfaragványok, 85-91; [Somogyvár] Mikó and Takács, Pannonia Regia, Cat. No I-57, 58, 111-15.

24 Tóth, “A pécsi székesegyház," 123-45; Marosi, “A pécsi román kori székesegyház," 549-64.

25 Takács, "The First Sanctuary," 15-43.

26 Cp. Marosi, “Az aracsi templom,” 19-45, 46-61. 
Another comparison can demonstrate that the Hungarian constructions of the Cistercians were adapted to the general plan of their contemporaries from the end of the twelfth century. E.g. the Pilis monastery or that in Transylvanian Cârța (Kerc) on the border of western Christianity, corresponded to the scale of such important and big centers of Cistercian monasticism as the Burgundian Fontenay or Maulbronn in South Germany. Even the small Hungarian abbey church in Bélapátfalva, which is consistent with a typical plan used for colonization buildings e.g. also in Poland, is based on the same scale indicated by a uniform geometric system, though not on the same size.

The architectural heritage of the Cistercians appears to be a rather uniform stylistic phenomenon. This uniformity was interpreted in the art historical literature as a contribution of the order, supposedly thanks to its own building organization. However, the hypothesis that the workers, the conversi of the order were among the rest of the craftsmen and builders of the order's churches and monasteries has been revealed as a legendary interpretation by art history. This legend was inspired by the strong tendency for regularity as well as the preference by the order of Citteaux for the Early Gothic style, which was the style of modern architecture in the most dynamic period of their reform and the intensive spread of the order in Europe in the second half of the twelfth century. Art history has identified Cistercian architecture as an early phenomenon of standardized constructions and a fairly functionalistic trend. It was considered to be a version of Burgundian Gothic or, given that the Burgundian High Romanesque models became simplified in less sumptuous constructions, a reduced style, a "Half Gothic" was developed by the order. The cult of the Cistercians in art history was actually a renewal of the nineteenth-century concept of a style of transition between the Romanesque and the Gothic.

Of course, it was the strongly centralized organization of the order that served as the basis for the uniformity and also for the different rules of construction and mainly for the insistence on simplicity and the rejection of luxurious solutions in their monasteries. Most rules and also restrictions were conceived as decisions of the Cîteaux general chapter. It would be a misunderstanding to find prescriptions for buildings or propagation of stylistic ideals in these decisions. The so-called Bernardine arrangement (mainly ground plan) has been interpreted in modern art historical literature not as a stylistic phenomenon, but as a symbolic factor stressing the identity of the order. ${ }^{27}$ Matthias Untermann understood it as an expression of a mentality which is often implied in the acts of the general chapters by the words forma ordinis. This concept appears as a threefold demand of uniformitas, habitus and the avoidance of all superfluum. This forma ordinis had its own history, with the greatest works of the second generation of the order in the second half of the twelfth

27 Krautheimers "Iconography of Archtecture" as methodological model: Krautheimer,

"Introduction to an 'Iconography'," 1-33. 
century. ${ }^{28}$ The most active period of the Hungarian Cistercians began with the privileges given by King Béla III to the Order and with the foundation of three abbeys in the 1180s. This is already the period between 1180 and 1240 which Untermann characterized as an epoch of traditions and innovations, when the Bernardine type was revised and also altered. In Hungary e.g. the abbeys of Pilisszentkereszt and Bélapátfalva adopt the traditional type, and Cârța shows the synthesis of the Bernardine plan with an elongated and polygonally closed choir. ${ }^{29}$

The Abbey in the Pilis mountain in the middle of the domain of the Árpáddynasty was built at the same time as the cathedral and the new royal palace of Esztergom. The ruins of the Cistercian abbey founded by King Béla III are situated in the village, which is now named Pilisszentkereszt, and Cârța, the foundation of his son King Imre probably in 1202, survives with high ruins and also a part of the choir still vaulted. Both monasteries show the same style, which is the first Gothic introduced in the buildings of Béla III in Esztergom. In recent art historical literature, it has been proposed that the monastery in the Pilis and the buildings in Esztergom must be considered as works of two separate workshops. This hypothesis is contrary to an earlier conception, according to which the two royal centers were separate. For a long time, a series of decorative stone carvings found in Esztergom were accepted as members of constructions in this royal city, and it has only been recently proved that in the eighteenth-century fragmentary stone carvings from the ruins of the Cistercian monastery were transported to Esztergom for secondary use. The fact itself that decorated pieces from Pilisszentkereszt could easily be considered as identical with those made by masters working is Esztergom testifies that they were not separate workshops but the same work team which finished in Esztergom a long building activity and Pilisszentkereszt was actually a new construction without a predecessor. This group of masons, which can be regarded as a royal workshop, went also to Cârța in Transylvania. ${ }^{30}$ Obviously, the constructions in Pilisszentkereszt and in Cârța were not the job of the monks but that of the royal founder. It is clear that the job of the Cistercians was to supervise the fulfilment of the prescriptions of the forma ordinis in their own construction. ${ }^{31}$

There is a tradition in Hungarian art history according to which the artistic import played an important role in the eleventh century, as the so-called Benedictine type became a kind of national production and fulfilled a domestic evolution. The renewal was attributed to cultural influences coming from the west,

28 Untermann, Forma Ordinis, 23-40, especially 39.

29 Marosi, Die Anfänge der Gotik, 162. The reduced version of the Bernardine disposition as a colonial type, see: Walicki, Sztuka polska, 171. ff.

30 Cârța Monastery as a work of royal craftsmen coming from the middle of the medieval country: Marosi, “Die Kathedrale 'Esztergom II’”, 69-142, here: Excourse, 108. ff.

31 Untermann, Forma Ordinis, passim. 
mainly from France. In Dezső Dercsényi’s synthesis of the history of art in the time of the Árpád dynasty these issues are exemplified through churches with transepts. It would be difficult to define why the existence of a transept could be the criterion of distinguishing French influences. Nevertheless, the illustration of the 1956 edition of Dercsényi's text contains two of the cathedrals of the thirteenth century: Alba Iulia, which has no French character outside of some early Gothic traits, and the only basilica with an ambulatory and radiating chapels, the second building of Kalocsa. Above these ground-plans three dispositions with transept are reproduced to indicate the routes of transmission: the Cistercian Bélapátfalva and the Praemonstratensian Ócsa with the Benedictine Vértesszentkereszt in the middle. ${ }^{32}$ The immense influence of the Cistercians in the early thirteenth is beyond question.

The very rational and well-organized building activity of the Cistercians and also the effective control by the top echelon of their centralized organization were presumably considered as unusual by contemporary observers. Of course, the Cistercian reform was the reform of the Benedictine order. Nobody thought about 1200 and in the early thirteenth century that this reform could be avoided. In order to prevent the excessive influence of secular people, to improve the education of the monks and to govern an order mainly the centralized organization was proposed. This reform was initiated by popes of the time about 1200, Innocent III and also Honorius III. Cistercian models and also advisers played an important role in the decisions of the Fourth Lateran Synod to strengthen the monks' discipline by organizing a central chapter and to hold sessions of the order's provinces in each third year. Abbot Uros of Pannonhalma, who built the third monastery church in the following decade, was among the participants of the sessions in 1215. The practical measures according to the synodal decisions were then issued by Pope Honorius III in his bull of 1225, which introduced a common chapter of the Hungarian Cistercian in the presence of two Cistercian abbots. The Bull of pope Honorius drew an ideal image of the monastery as opposed to the actual situation of decline and disorder. In this allegory the Tower of Babel is in a contrast to Paradise, which is the realm of Wisdom and the habitat of the second Adam. An archaeological exhibition held in Pannonhalma in 2000 on the occasion of the Millenary of the Benedictines in Hungary chose a quotation from Honorius' 1225 bull for its title: Paradisum plantavit. ${ }^{33}$

It seems that the necessary reform as well as the solution of the problems by adopting the experience of the Cistercians influenced the spread of the regular monastery building under the evident will to imitation. Quadratic interior courts framed by open galleries and surrounded by the most important common rooms, including

32 Dercsényi, “A román stílusú művészet fénykora," 77 (Fig. 50, cp. note 10).

33 The Hungarian translation of the 1225 letter of Pope Honorius III to the prelates of Hungary edited in the catalogue Marosi, "Benedictine Building Activity," 651-58. 
the chapterhouse and refectory of the monastery, appear evidently from about 1220 on in Hungarian Benedictine architecture. Pilisszentkereszt or another Cistercian building could provide the prototype which-besides the later transformed part of building-is represented by fragments of the arcades of its wings. In the building complex of the Abbey of Pécsvárad double bases of slender columns as typical structural members witness a similar construction. They represent a cloister which could be partly reconstructed on the north side of the Somogyvár abbey church. This partially rebuilt corner does not correspond in all details to a possible theoretical reconstruction, and it was a bigger mistake to use the very sensitive original sculpture for this demonstration instead of modern copies. The Somogyvár cloister also had a rich figural decoration on its capitals and imposts. The same hands of artists produced a sitting statue of the Holy Virgin, too. It could be placed in the new cloister, but also anywhere in the monastery which was rebuilt about 1200 . In those years serious conflicts between the inhabitants of diverse nationalities were reported. In course of the procedure after the dispute it was declared that presumably the Latin (i.e. French) monks could have this single monastery in Hungary, when Greeks had so many houses. Another richly decorated cloister belonged to the abbey of the influential Bár-Kalán family in Pusztaszer. When fragments of statue columns were found in the foundations of a later cloister, the archaeologist of the excavation thought that they were jamb figures of a portal, but even the finding site could prove that the pieces in question were parts of a cloister. ${ }^{34}$

It could not last longer than only one or two decades, because the monastery was destroyed in the 1241-1242 Mongol invasion. Many Benedictine monasteries could not survive the destruction and had no power enough to rebuild their buildings. The same circumstances, which necessitated a reform: lack of centralization, economic weakness and sporadicity were the main cause of the sudden end of the Benedictine culture flourishing immediately before the invasion.

We already quoted Dercsényi's illustration, in which the ground-plan of Ócsa represents the Praemonstratensians, a reform order, a nearly contemporary parallel to the Cistercians. In the twelfth century and also at the beginning of the thirteenth they were in fact in direct contact with the Cistercians who exercised a kind of control over the order, whose rules wore not derived from the Benedictine rules but were based on the rules of St Augustine. Mainly the centralized organization of the order could correspond to the Cistercian model. The main difference between these reform orders concerned their patronage. While the Cistercians in Hungary were mostly under royal patronage (mainly after the visit of a delegation of Cîteaux to the Court of Béla III in 1183), the Praemonstratensians were mainly foundations by private patrons. As canons, the Praemonstratensians had no ascetic ideals but

34 Marosi, "Benedictine Building Activity," 651-58. 
exercised practical care and led the life of parish churches. Concentrating on the care of souls, they were preferred in recently colonized regions as e.g. the northern regions of Germany conquered from the Slaves. It seems that they played an important role also in pastoral ministry and missionary work at the beginning of the transformation of aristocratic possessions and in the missionary activities in Hungary. The head of the Hungarian circaria of the order was the convent of Váradhegyfok (part of Oradea), founded at an unknown date about 1130 immediately from Prémontré. The other immediate filia of Prémontré was the monastery of Leles (Lelesz). Both these monasteries were under royal patronage. Váradhegyfok was the mother of the majority of the Hungarian foundations and the head of the order's province which was described in its nearly greatest extent in the catalogues of the order, namely in that of Ninive in $1234 .^{35}$

Praemonstratensian architecture cannot be envisioned either as mirroring specific liturgical features like the Benedictine monasteries or being a kind of parallel to the forma ordinis of the Cistercians. A simple look at the disposition of some known or conserved buildings shows the lack of a preferred building type, from the little provostry of Gyulafirátót corresponding to a small Cistercian monastery to arrangements of Benedictine character like Majk, Türje and also the impressive and very distinguished Zsámbék. Mórichida (or Árpás) on the river Rába shows a very simple, nearly rural type and this also in a very irregular form. It seems that Ócsa with a transept and the monastery of Bíňa (Bény) with a single nave but with a double-towered west part and also a three-apsidal east part, correspond to the preference of the order for a more ample sanctuary. In Ócsa the recent restoration brought also the foundations of the choir screens into light.

More variations than the choice of building types is evidenced by the monuments of the preserved Praemonstratensian buildings. Two monuments of the early thirteenth century might go back to the royal building activity in Esztergom, without having any connection to each other. In Bíňa, a foundation of the aristocratic family Hont Pázmán, which was provided with donations in 1217 when the patron was leaving for a crusade, there was apparently a mason at work who still knew earlier stylistic phases of the royal workshop. Ócsa is a modern building, having its roots in the early Gothic works in Esztergom and also in the Cistercian monasteries of the Pilis mountains and Cârța. Maybe, it cannot be derived directly from the Esztergom workshop itself but from its filiation at the metropolitan seat of Kalocsa. As no circumstances of the foundation are known, the stylistic and also geographic situation could very

35 For the history of Praemonstratesians in Hungary and its written sources, see: Oszvald, "Adatok," 231-54; Körmendi, “A 13. századi premontrei monostorjegyzékek," 61-72. About the monuments of the Order's monasteries up to the end of the first third of the thirteenth century, see: Marosi, Die Anfänge der Gotik, passim. 
possibly point to a royal building. Three nearly contemporary churches built by rich aristocrats with important political power in the thirteenth century show that there is no common denominator among the churches under their patronage outside of the style of their architectonic members and decoration. It seems that the Gyulafirátót monastery of the Rátót family as well as Türje monastery were built by a local workshop with its center in the town of Veszprém, seat of a bishopric.

It can be concluded that contrary to partly surviving hypotheses and forgeries in old art historical literature no royal court and also no monastic order dealt directly with architecture or building praxis, including schools of architecture. Their attitude to architecture was different, corresponding to their liturgy and to the representation of their self-image.

\section{Bibliography}

Bónis, György. "A somogyvári formuláskönyv" [The Formulary of Somogyvár]. In Emlékkönyv Kelemen Lajos születésének nyolcvanadik évfordulójára [Memorial Volume in Honor of the $80^{\text {th }}$ Birthday of Lajos Kelemen], 117-33. Cluj: Tudományos K., 1957.

Conant, Kenneth John. Cluny: les églises et la maison du chef de l'ordre. Mâcon: Protat Frères, 1968.

Dercsényi, Dezső. "A honfoglalás és az államalapítás korának művészete (A XI. század utolsó harmadáig)" [Art at the Time of the Hungarian Conquest and State Foundation (until the Last Third of the $11^{\text {th }}$ Century)]. Magyarországi müvészet a honfoglalástól a XIX. századig [Art in Hungary from the Conquest Period until the $19^{\text {th }}$ Century], edited by Dezső Dercsényi, 9-30. Budapest: Képzőművészeti Alap Kiadóvállalata, 1956.

Dercsényi, Dezső. “A pécsi műhely kora (A XI. század végétől a XII. század utolsó évtizedéig)" [The Period of the Pécs Workshop (From the End of the $11^{\text {th }}$ Century until the Last Decade of the $12^{\text {th }}$ Century)]. Magyarországi müvészet a honfoglalástól a XIX. századig [Art in Hungary from the Conquest Period until the $19^{\text {th }}$ Century], edited by Dezső Dercsényi, 31-48. Budapest: Képzőmüvészeti Alap Kiadóvállalata, 1956.

Dercsényi, Dezső. “A román stílusú művészet fénykora (A XII. század végétől a tatárjárásig)" [The Heyday of the Romanesque Art (From the End of the $12^{\text {th }}$ Century until the Mongol Invasions]. Magyarországi müvészet a honfoglalástól a XIX. századig [Art in Hungary from the Conquest Period until the $19^{\text {th }}$ Century], edited by Dezső Dercsényi, 49-118. Budapest: Képzőművészeti Alap Kiadóvállalata, 1956. 
Entz, Géza. "Még egyszer a nyugati karzatokról" [Once More About Eastern Galleries]. Épités- Épitészettudomány 12, no. 1-4 (1980): 133-41.

Entz, Géza. "Nyugati karzatok románkori építészetünkben” [Western Galleries in the Romanesque Architecture of Hungary]. Müvészettörténeti Értesitő 8 (1959): 130-42.

Evans, Joane. The Romanesque Architecture of the Order of Cluny. Cambridge: The University Press, 1938.

Fügedi, Erik. "Sepelierunt corpus eius in proprio monasterio: A nemzetségi monostor" [Sepelierunt corpus eius in proprio monasterio: The Kindred Monastery]. Századok 125, no. 1-2 (1991): 35-67.

Gerevich, Tibor. Magyarország románkori emlékei [Monuments of Romanesque Art of Hungary]. Budapest: Müemlékek Országos Bizottsága, 1938.

Györffy, György. Az Árpád-kori Magyarország történeti földrajza [Historical Geography of Hungary in the Árpádian Age]. Vol. 1-4. Budapest: Akadémiai Kiadó, 1963-1998.

Hervay, Levente. "A bencések és apátságaik története a középkori Magyarországon" [History of Benedictines and Their Abbeys in Medieval Hungary]. In Paradisum plantavit: Bencés monostorok a középkori Magyarországon / Benedictine Monasteries in Medieval Hungary, edited by Imre Takács, 461-547. Pannonhalma: Pannonhalmi Bencés Főapátság, 2001.

Hoffmann, Wolfbernhard. Hirsau und die "Hirsauer Bauschule". Munich: Schnell \& Steiner, 1950.

Hollné Gyürky, Katalin. A Buda melletti kánai apátság feltárása [The Archaeological Research of the Abbey of Kána near Buda]. Budapest: Akadémiai Kiadó, 1996. Ipolyi, Arnold. "Magyarország középkori emlékszerü építészete" [Monumental Architecture of Hungary]. In Ipolyi Arnold magyar mütörténelmi tanulmányai [Art Historical Studies of Arnold Ipolyi]. Budapest: Ráth, 1889.

Karsai, Géza. "Középkori vízkereszti játékok: A győri 'Tractus stellae’ és rokonai” [Medieval Epiphany Plays: The Tractus stellae of Györ and Its Analogies]. In A Pannonhalmi Föapátsági Szent Gellért Föiskola évkönyve az 1942/43 tanévre [Annual of the St Gerard College of Archabbey of Pannonhalma for the year 1942/43], 73-112. Pannonhalma: Pannonhalmi Főapátsági Szent Gellért Főiskola, 1943.

Körmendi, Tamás. “A 13. századi premontrei monostorjegyzékek magyar vonatkozásairól" [About Hungarian Concerns of the Praemonstratensian Abbey Lists of the $13^{\text {th }}$ Century]. Történelmi Szemle 43, no. 1-2 (2001): 61-72.

Krautheimer, Richard. "Introduction to an 'Iconography of Mediaeval Architecture'." Journal of the Warburg and Courtauld Institutes 5 (1942): 1-33. https://doi.org/10.2307/750446. 
László, Csaba. "Régészeti adatok Pannonhalma építéstörténetéhez" [Archaeological Contribution to the Building History of Pannonhalma]. In Mons Sacer 9961996: Pannonhalma 1000 éve I. [Mons Sacer 996-1996: Thousand Years of Pannonhalma], edited by Imre Takács, 143-69. Pannonhalma: Szt. Gellért Hittudományi Főiskola, 1996.

Levárdy, Ferenc. "Pannonhalma építéstörténete. I." [History of Construction of the Monastery Pannonhalma. I.]. Müvészettörténeti Értesitö 8, no. 1 (1959): 27-43. Levárdy, Ferenc. "Pannonhalma építéstörténete. II." [History of Construction of the Monastery Pannonhalma. II.]. Müvészettörténeti Értesitö 8, no. 2-3 (1959): 101-29.

Levárdy, Ferenc. "Pannonhalma építéstörténete. III." [History of Construction of the Monastery Pannonhalma. III.]. Müvészettörténeti Értesitö 8, no. 4 (1959): $220-31$.

Mályusz, Elemér. Egyházi társadalom a középkori Magyarországon [Ecclesiastic Society in Medieval Hungary]. Budapest: Akadémiai Kiadó, 1971.

Marosi, Ernő. Die Anfänge der Gotik in Ungarn: Esztergom in der Kunst des 12-13. Jahrhunderts. Budapest: Akadémiai Kiadó, 1984.

Marosi, Ernő. "Az aracsi templom, kortársai között / Crkva u Arači, među svojim savremenicima" [Arača Church among Its Contemporaries]. In Aracs: A Pusztatemplom múltja és jövője / Arača: Prošlost i budućnost crkve u pustari [Arača: The Past and Future of the Desolated Church], edited by Karolina Biacsi, Endre Raffay, and Anna Tüskés, 19-61. Novi Sad: Forum Könyvkiadó, 2018.

Marosi, Ernő. "Bencés építészet az Árpád-kori Magyarországon: A 'rendi építőiskolák' problémája" [Architecture of the Benedictines in Hungary in the Árpád period: The Problem of the "Monastic Schools"]. In Mons Sacer 9961996: Pannonhalma 1000 éve I. [Mons Sacer 996-1996: Thousand Years of Pannonhalma], edited by Imre Takács, 131-42. Pannonhalma: Szt. Gellért Hittudományi Főiskola, 1996.

Marosi, Ernő. "Benedictine Building Activity in the Thirteenth Century." In Paradisum plantavit: Bencés monostorok a középkori Magyarországon / Benedictine Monasteries in Medieval Hungary, edited by Imre Takács, 651-57. Pannonhalma: Pannonhalmi Bencés Főapátság, 2001.

Marosi, Ernő. "Die Kathedrale 'Esztergom II' der Bau der St. Adalbertskathedrale im 12. Jahrhundert." Acta Historiae Artium Academiae Scientiarum Hungaricae 59, no. 1 (2018): 69-142. https://doi.org/10.1556/170.2018.59.1.3.

Marosi, Ernő, ed. Magyarországi müvészet 1300-1470 körül, I-II [Art in Hungary around 1300-1470]. Budapest: Akadémiai Kiadó, 1987.

Marosi, Ernő. "Megjegyzések a középkori magyarországi művészet liturgiai vonatkozásaihoz" [Remarks on the Liturgical Aspects of Medieval Hungarian Art]. 
In "Mert ezt Isten hagyta...": Tanulmányok a népi vallásosság köréböl [Because this is what God left...": Studies on Popular Religiosity], edited by Gábor Tüskés, 88-116. Budapest: Magvető, 1986.

Marosi, Ernő. "A pécsi román kori székesegyház narratív reliefjeiről [About the Narrative Reliefs of the Romanesque Cathedral in Pécs]." In "Ez világ, mint egy kert...": Tanulmányok Galavics Géza tiszteletére [“This World is like a Garden...": Studies in Honor of Géza Galavics], edited by Orsolya Bubryák, 549-64. Budapest: Gondolat, 2010.

Marosi, Ernő. "Pfarrkirchen im mittelalterlichen Ungarn im Spannungsfeld der beharrenden Kräfte der Gesellschaft und zunehmender Bildungsansprüche.” In Pfarreien im Mittelalter: Deutschland, Polen, Tschechien und Ungarn im Vergleich, edited by Nathalie Kruppa and Leszek Zygner, 201-22. Göttingen: Vandenhoeck \& Ruprecht, 2008.

Marosi, Ernő. “A Pray-kódex húsvéti képsorához" [To the Easter Cycle of Codex Pray]. In Szöveg - emlék - kép [Text - Memory - Image], edited by László Boka and Judit P. Vásárhelyi, 11-24. Budapest: Országos Széchényi KönyvtárGondolat Kiadó, 2011.

Mettler, Alfons. "Die zweite Kirche in Cluni und die Kirchen in Hirsau nach den 'Gewohnheiten' des XI. Jahrhunderts.” Zeitschrift für Geschichte der Architektur 3 (1909/10): 273-87. https://doi.org/10.11588/diglit.22223.49.

Mettler, Alfons. "Die zweite Kirche in Cluni und die Kirchen in Hirsau nach den 'Gewohnheiten' des XI. Jahrhunderts.” Zeitschrift für Geschichte der Architektur 4 (1910/11): 1-16. https://doi.org/10.11588/diglit.22224.6.

Mezey, László. "Autour de la terminologie ecclésiastique et culturelle de la Hongrie médiévale.” Acta Antiqua Academiae Scientiarum Hungaricae 23, no. 3-4 (1975): 377-86.

Mikó, Árpád and Imre Takács, eds. Pannonia Regia: Müvészet a Dunántúlon 10001541 [Pannonia Regia: Art in Transdanubia 1000-1541]. Budapest: Magyar Nemzeti Galéria, 1994.

Oszvald, Ferenc. "Adatok a magyarországi premontreiek Árpád-kori történetéhez" [Data to the Hungarian Praemonstratensians in the Árpádian Period]. Müvészettörténeti Értesítö 6 (1957): 231-54.

Papp, Szilárd and Tibor Koppány. "Somogyvár." In Paradisum plantavit, Bencés monostorok a középkori Magyarországon / Benedictine Monasteries in Medieval Hungary, edited by Imre Takács, 350-58. Pannonhalma: Pannonhalmi Bencés Főapátság, 2001.

Schürenberg, Lisa. "Mittelalterlicher Kirchenbau als Ausdruck geistiger Strömungen.” Wiener Jahrbuch für Kunstgeschichte 14 (1950): 23-46. 
Stanojev, Nebojša. "A dombói (Rakovac) Szent György monostor szentélyrekesztői” [The Rood-Screens of the St George Monastery in Rakovac]. In A középkori Dél-Alföld és Szer [Medieval Southern Great Hungarian Plain and Szer], edited by Tibor Kollár, 383-428. Szeged: Csongrád Megyei Levéltár, 2000.

Szakács, Béla Zsolt. "Ákos, református templom: Művészettörténeti elemzés” [Acâș, Calvinist Church: An Art Historical Analysis]. In Középkori egyházi épitészet Szatmárban [Medieval Ecclesiastical Architecture in Szatmár], edited by Tibor Kollár, 86-91. Nyíregyháza: Szabolcs-Szatmár-Bereg Megyei Önkormányzat, 2011.

Szakács, Béla Zsolt. “Állandó alaprajzok - változó vélemények?” [Constant Groundplans - Changing Meanings?]. In Maradandóság és változás: müvészettörténeti konferencia, Ráckeve, 2000 [Endurance and Change: An Art Historical Conference, Ráckeve, 2000], edited by Szilvia Bodnár et al., 25-38. Budapest: MTA Művészettörténeti Kutatóintézet, Képző- és Iparművészeti Lektorátus, 2004.

Szentpétery, Emericus, ed. Scriptores rerum Hungaricarum tempore ducum regumque stirpis Arpadianae gestarum 2. Budapest: Academie Litter. Typ. Universitatis, 1938.

Takács, Imre. "The First Sanctuary of the Second Cathedral of Gyulafehérvár (Alba Iulia, RO)." Acta Historiae Artium Academiae Scientiarum Hungaricae 53, no. 1 (2012): 15-43. https://doi.org/10.1556/ahista.53.2012.1.3.

Takács, Imre. "Pannonhalma újjáépítése a 13. században [The $13^{\text {th }}$-Century Rebuilding of Pannonhalma]." In Mons Sacer 996-1996: Pannonhalma 1000 éve I. [Mons Sacer 996-1996: Thousand Years of Pannonhalma], edited by Imre Takács, 170-236. Pannonhalma: Szt. Gellért Hittudományi Főiskola, 1996.

Tomaszewski, Andrzej. Romańskie kościoły z emporami zachodnimi na obszarze Polski, Czech i Węgier [Romanesque Churches with Western Galleries on the Territory of Poland, Bohemia, and Hungary]. Wrocław: Zakład Narodowy im. Ossolińskich, Wydawnictwo, 1974.

Tóth, Melinda. "A müvészet Szent István korában" [Art in the Period of St Stephen]. In Szent István és kora [St Stephen and His Age], edited by Ferenc Glatz and József Kardos. Budapest: MTA Történettudományi Intézet, 1988.

Tóth, Melinda. "A pécsi székesegyház kőszobrászati díszítése a románkorban" [Stone Sculpture Decoration of the Pécs Cathedral in the Romanesque Period]. In Pannonia Regia: Müvészet a Dunántúlon 1000-1541 [Pannonia Regia: Art in the Transdanubia 1000-1541], edited by Árpád Mikó and Imre Takács, 123-53. Budapest: Magyar Nemzeti Galéria, 1994.

Tóth, Sándor. "A felsőörsi préposti templom nyugati kapuja" [The West Portal of the Provostry Church in Felsöörs]. Müemlékvédelmi Szemle 10, no. 1-2 (2000): 53-76. 
Tóth, Sándor. "Felsőörs késő román templomtornya” [The Late Romanesque Church Tower in Felsőörs]. Müvészet 21, no. 2 (1980): 22-27.

Tóth, Sándor. Román kori kőfaragványok a Magyar Nemzeti Galéria régi magyar gyújteményében [Romanesque Stone Scupltures in the Collection of Old Hungarian Art of the Hungarian National Gallery]. Budapest: Magyar Nemzeti Galéria, 2010.

Tóth, Sándor. “Szekszárd.” In Paradisum plantavit: Bencés monostorok a középkori Magyarországon / Benedictine Monasteries in Medieval Hungary, edited by Imre Takács, 339-41. Pannonhalma: Pannonhalmi Bencés Főapátság, 2001.

Tóth, Sándor. "Tihany.” In Paradisum plantavit: Bencés monostorok a középkori Magyarországon / Benedictine Monasteries in Medieval Hungary, edited by Imre Takács, 335-38. Pannonhalma: Pannonhalmi Bencés Főapátság, 2001.

Tóth, Sándor. “Zselicszentjakab.” In Paradisum plantavit: Bencés monostorok a középkori Magyarországon / Benedictine Monasteries in Medieval Hungary, edited by Imre Takács, 342-45. Pannonhalma: Pannonhalmi Bencés Főapátság, 2001.

Tóth, Sándor. "A 11-12. századi Magyarország Benedek-rendi templomainak maradványai" [The Remnants of the $11^{\text {th }}-12^{\text {th }}$-Century Benedictine Churches in Hungary]. In Paradisum plantavit: Bencés monostorok a középkori Magyarországon / Benedictine Monasteries in Medieval Hungary, edited by Imre Takács, 229-66. Pannonhalma: Pannonhalmi Bencés Főapátság, 2001.

Untermann, Matthias. Forma Ordinis: Die mittelalterliche Baukunst der Zisterzienser. Munich: Deutscher Kunstverlag, 2001.

Valter, Ilona. "Újabb régészeti kutatások a zsámbéki prépostsági romban 1986-1991" [Recent Archaeological Research in the Ruins of the Zsámbék Provostry]. Müemlékvédelmi Szemle 1, no. 2 (1991): 24-8.

Walicki, Michal, ed. Sztuka polska przedromańska i romańska do schylku XIII wieku [Polish Pre-Romanesque and Romanesque Art until the End of the $13^{\text {th }}$ Century]. Warsaw: Panstwowe Wydawnictwo Naukowe, 1971.

Závodszky, Levente. A Szent István, Szent László és Kálmán korabeli törvények és zsinati határozatok forrásai [The Sources of the Laws and Synodal Constitutions in the Time of St Stephen, St Ladislas and Coloman]. Budapest: Szent István Társulat, 1904. 

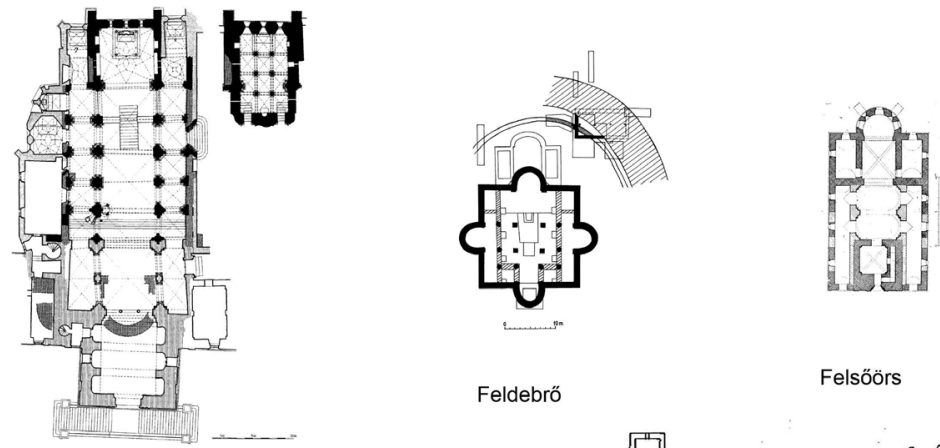

Pannonhalma

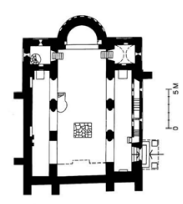

Boldva

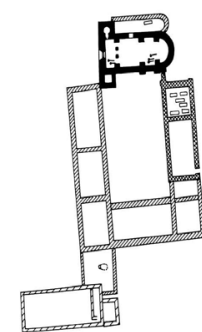

Kána

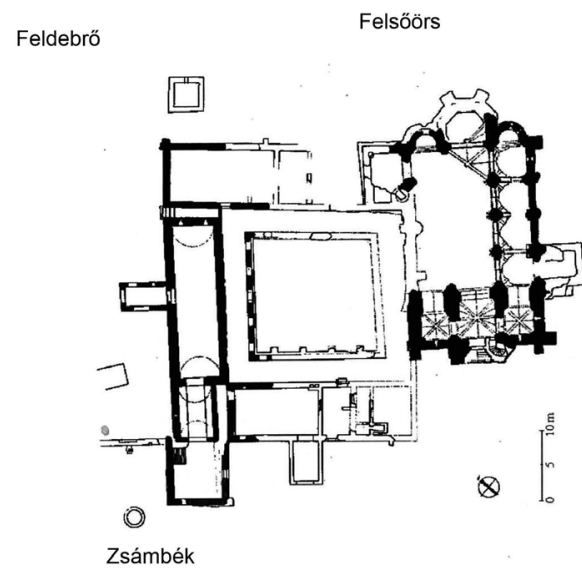

Zsámbék

Figure 1 Comparative table of plans of Hungarian monastic buildings 


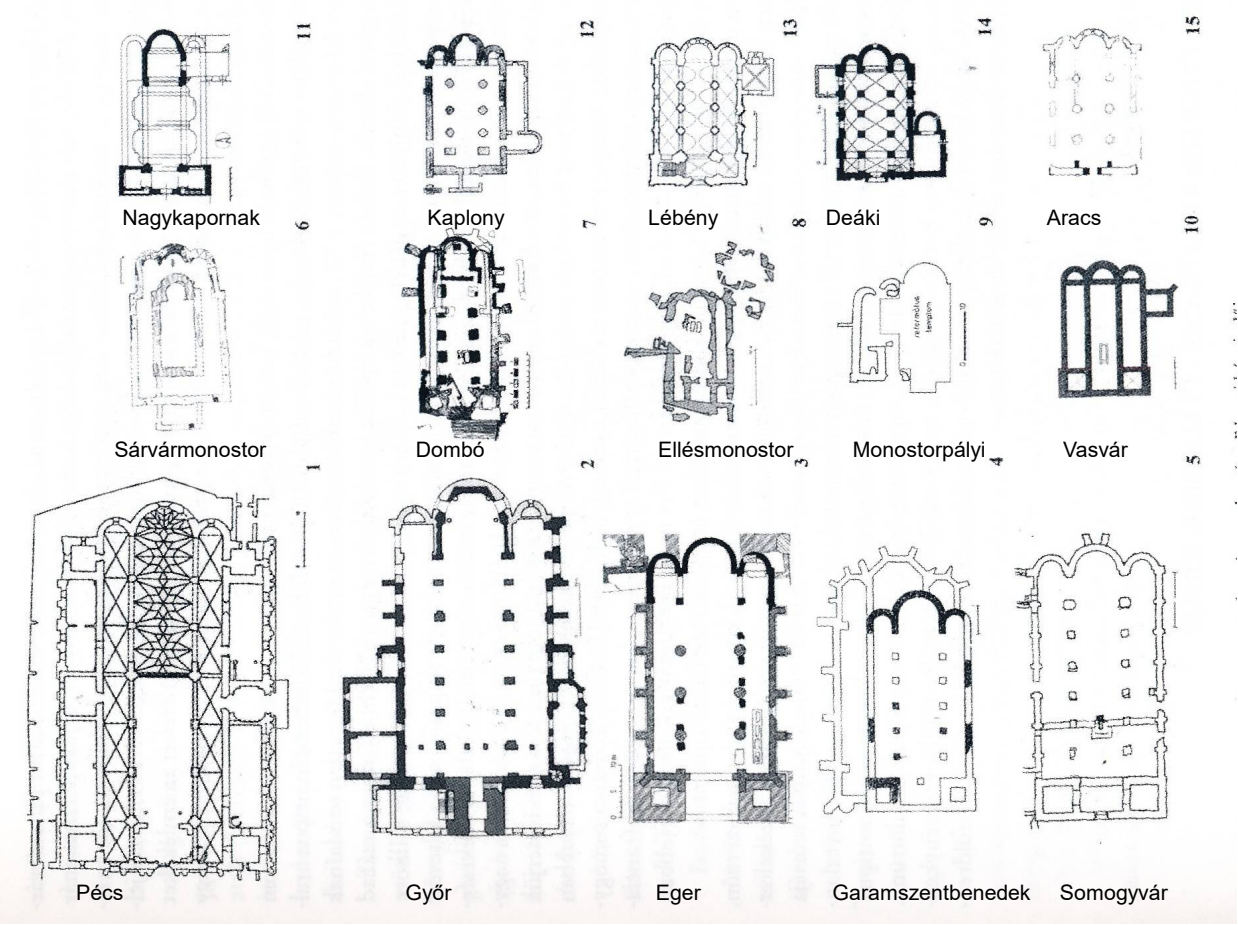

Figure 2 Three-apsidal plans of Hungarian Romanesque buildings (cathedrals and monasteries) - after Szakács, "Állandó alaprajzok."

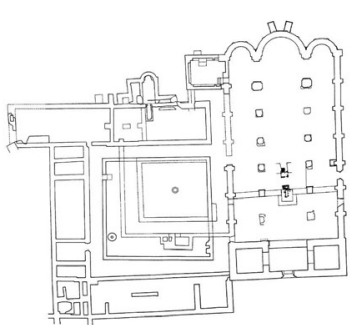

Somogyvár

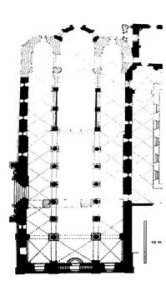

Regensburg, St. Jakob

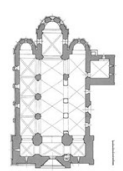

Ják

Figure 3 Comparative table of plans of Romanesque monasteries (Somogyvár, Ják and Regensburg, St James) 

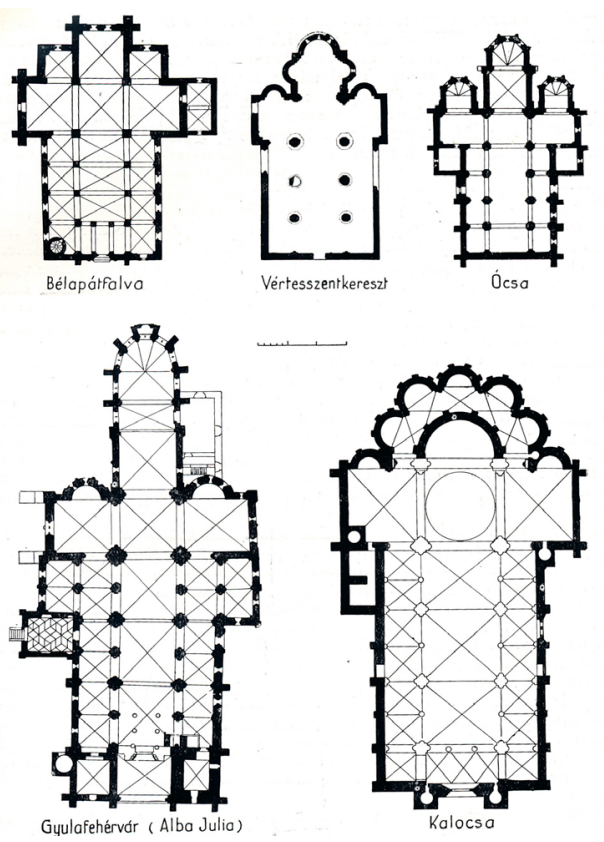

Figure 4 Late Romanesque and Early Gothic churches with transept. Dercsényi, "A pécsi mühely kora", 77.

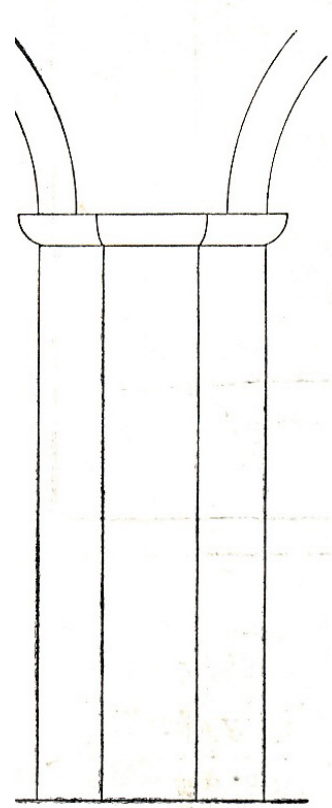

Ócša
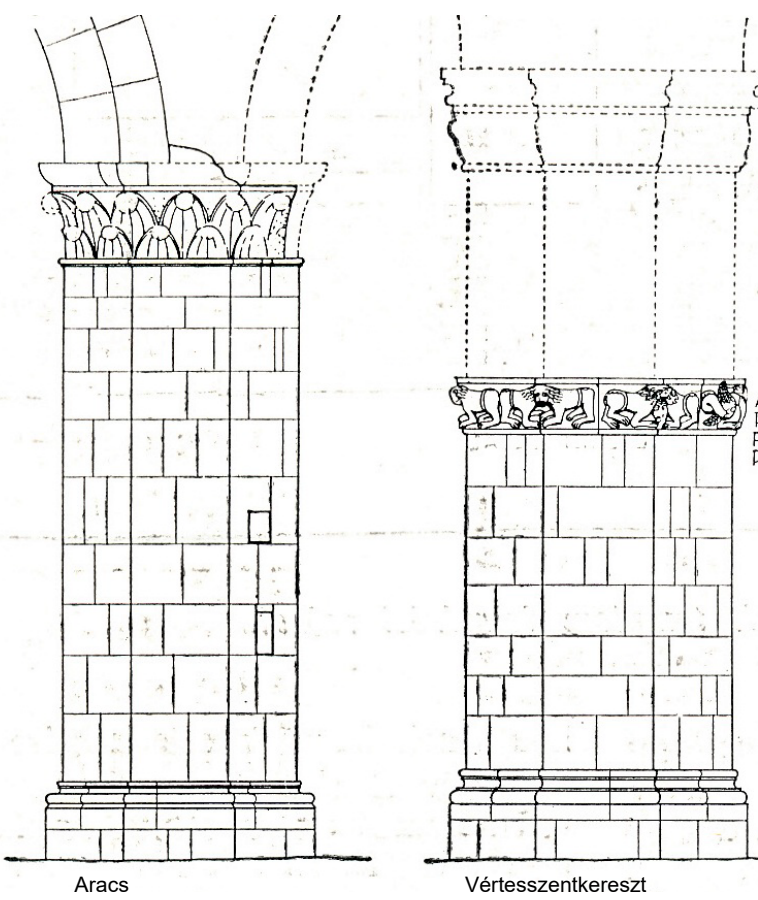

Vértesszentkereszt

Figure 5 Octagonal pillars in Hungarian monastic buildings 

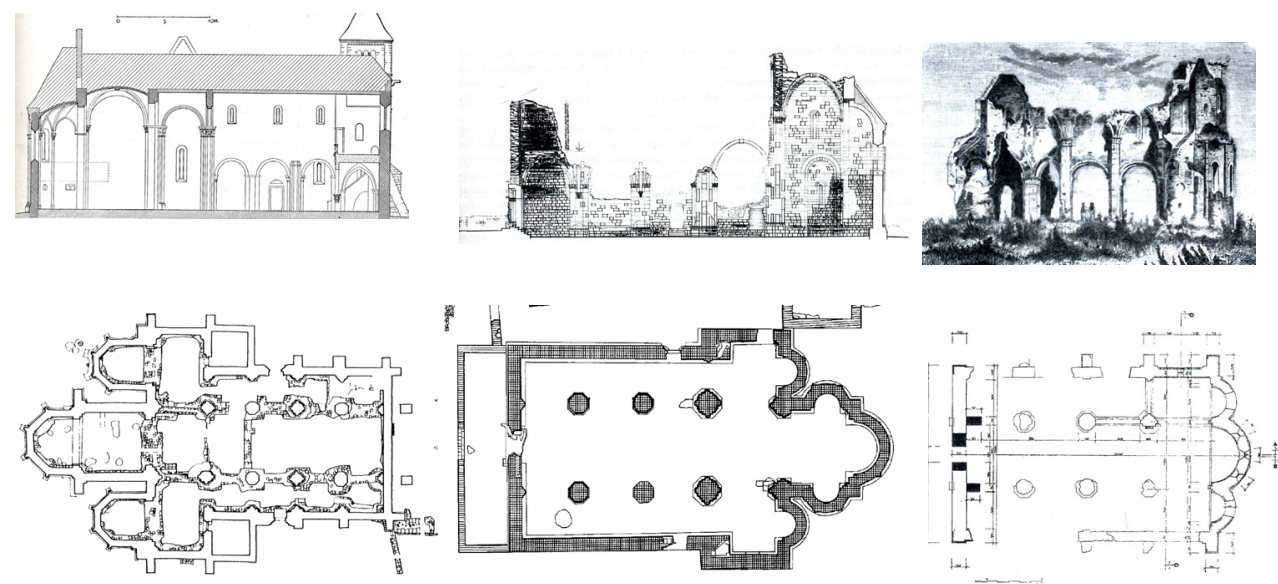

Ócsa

Vértesszentkereszt

Aracs

Figure 6 Plans of the monasteries, as on Figure 5
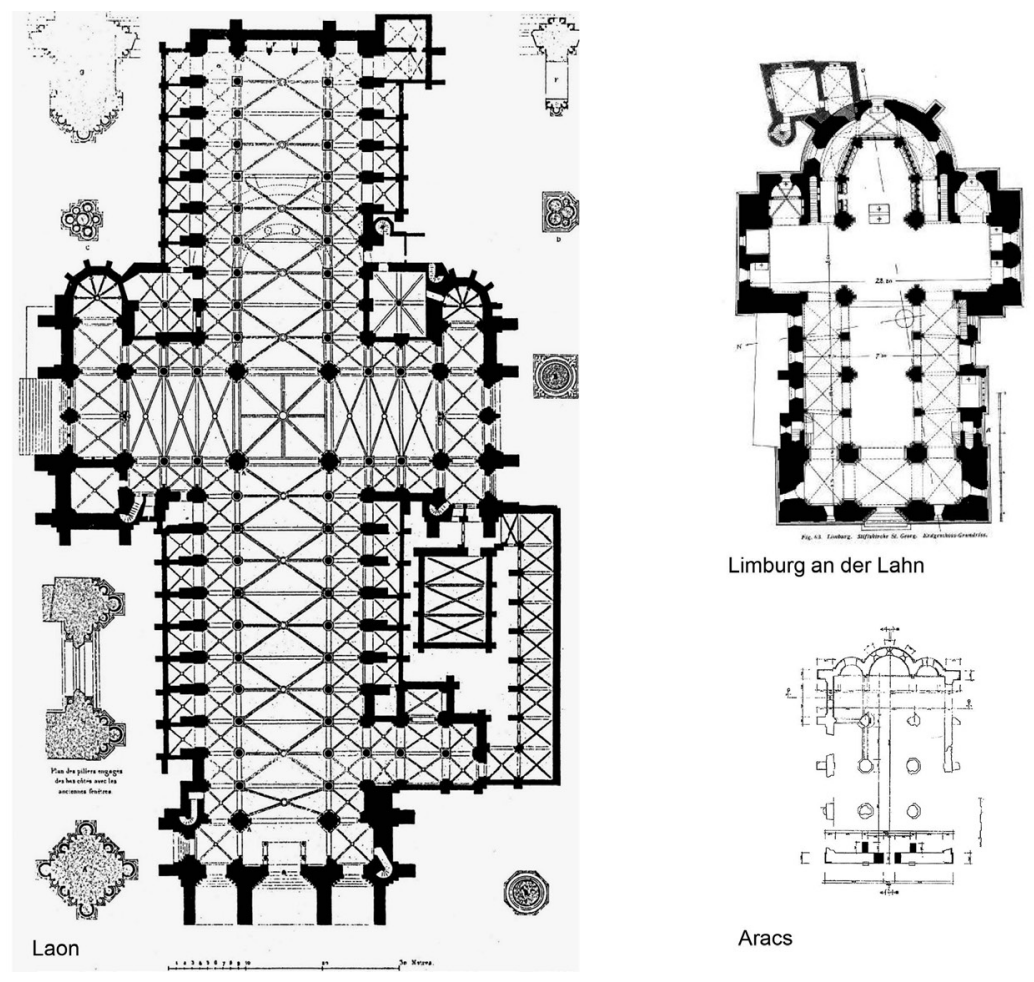

Limburg an der Lahn

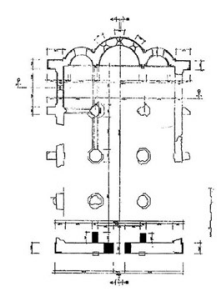

Aracs

Figure 7 Comparative table of plans of early Gothic buildings in Laon (cathedral), Limburg a.d. Lahn (monastery), Arača (monastery) 


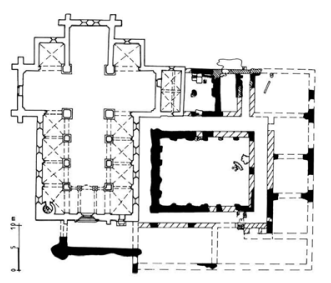

Bélapátfalva

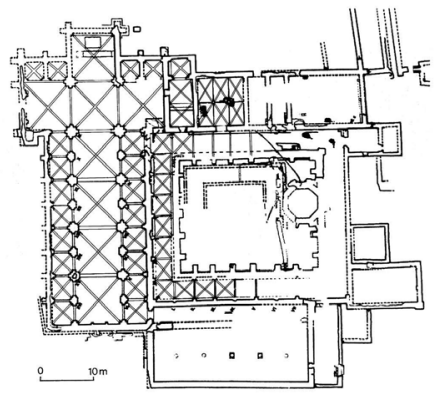

Pilisszentkereszt

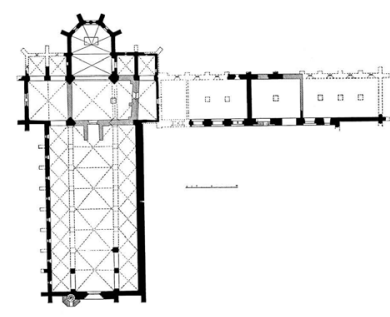

Kerc

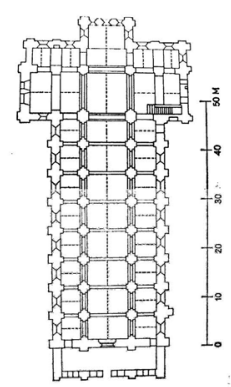

Fontenay

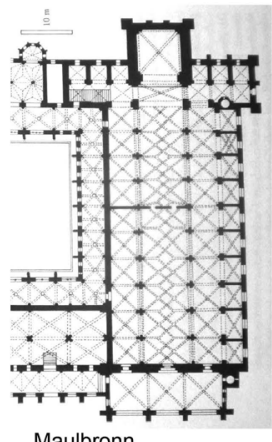

Maulbronn

Figure $\mathbf{8}$ Comparative table of plans of Cistercian monasteries in Hungary and abroad 